\title{
Stand and Deliver: Private Property and the Politics of Global Dispossession
}

\author{
Stefan Andreasson \\ Queen's University Belfast
}

Property rights necessarily generate violent, and oftentimes lethal, processes of dispossession. While liberal theorists from Locke to Hayek consider property rights as an essential and emancipatory component of human freedom, they fail to consider societal power asymmetries impeding the ability of property rights to protect the interests of the weak and marginalised. If property rights produce freedom and prosperity, they do so very selectively. More obvious is the ongoing historical process of already propertied classes making 'clever usurpation into an irrevocable right' by extending private property regimes along two key dimensions - type and space. Examining various uses of private property over time reveals processes whereby relatively basic notions of private property, enforced by a Weberian state at the local level in the early era of industrialisation, are extended to encompass new and sophisticated forms of property that are enforced globally via international institutions. Two contemporary empirical cases of using property rights are examined in this paper: land reform in Southern Africa (specifically Zimbabwe) and intellectual property rights. In this context of ongoing dispossession, further privatisation and commodification can only exacerbate contemporary problems of marginalisation and dispossession.

The true founder of civil society was the first man who, having enclosed a piece of land, thought of saying 'This is mine', and came across people simple enough to believe him (Rousseau, 1994, p. 55).

The greatest offence against property was to have none (Thompson, 1968, p. 66).

Surveying the condition of his contemporary world, Rousseau noted dejectedly the miserable state of those rendered destitute by the civil law, a law of and for the propertied classes.

Such was, or must have been, the origin of society and of laws, which put new shackles on the weak and gave new powers to the rich; which destroyed natural freedom irretrievably, laid down for all time the law of property and inequality, made clever usurpation into an irrevocable right, and henceforth subjected, for the benefit of a few ambitious men, the human race to labour, servitude and misery (Rousseau, 1994, p. 69 emphasis added).

Rejecting Locke's glorification of private property, and perhaps presaging Proudhon's claim that 'all property is theft', Rousseau formulated an understanding of the social consequences of bourgeois statecraft that remains a vivid illustration of how capitalist accumulation on a global scale continues to affect the world's poor. ${ }^{1}$

The collective Western memory of English enclosure movements, and similar processes of dispossession elsewhere in modernising Europe, has not entirely van- 
ished. It is, however, largely a memory of a bygone era of ruthless capitalism that has since been tempered by twentieth-century social reforms, culminating in the post-WWII 'historical compromise' between state, capital and labour, and the subsequent emergence of the welfare state. Yet the merciless dispossession brought on by earlier forms of accumulation remains a reality for much of mankind (compare with Perelman, 2000). ${ }^{2}$ While official Western proclamations may condemn the most brutal manifestations of contemporary capitalism as it is exercised abroad, the West still plays a pivotal role in this process of systematic marginalisation and immiseration of people beyond its 'civilisational' boundaries. 'The hypocrisy is that bourgeois civilization in Europe, plus plunder, primitive accumulation and famine in the colonial world were part of the same overarching liberal ideals' (Bracking and Harrison, 2003, p. 5; compare with Davis, 2001). And, recalling Proudhon's outrage, why not steal when one is not likely to be held accountable?

Early modern European thought on property relations, and the 'rightful' means by which states act to reinforce unequal relations between those in possession and those dispossessed remains relevant for understanding global capitalism today and why Western rhetoric regarding global development is not matched in deeds. At the root of the problem of violent exploitation and dispossession stands the problem of private property as conceived by Locke, and subsequently expounded upon by a vast array of liberal scholars. The problem essentially arises out of the tension between, on the one hand, insisting on private property as a prerequisite for freedom and, on the other hand, accepting the inevitable process of violence in establishing property rights and the subsequently very unequal distribution of property in capitalist society. This tension unfolds and intensifies in the era of capitalism as the use of property rights expands; it is a prominent phenomenon in the Global South today.

In making the link between the origins of private property and historical processes of dispossession, this paper considers three key propositions. First, there is an important link between the essentially liberal project of primitive and capitalist accumulation and liberal thinkers, from John Locke to Friedrich Hayek, and the ideology and policy of international financial institutions managing the global economy today - the International Monetary Fund (IMF), the World Bank and the World Trade Organization (WTO). Second, an examination of historical and contemporary processes that turn human and natural resources into property, thus creating the enormous inequalities in ownership and wealth that exist today, suggests that accumulation is necessarily a violent process. It is upon the contrived separation of accumulation, as a supposedly 'natural' and benign economic process, from its violent nature and consequences that support (ideological, political, financial, military) for the world economy as currently constituted depends. Third, the use of basic forms of property rights at the local level has expanded over type and space into the application of sophisticated forms of property rights on a global level today; land reform in Southern Africa (specifically 
Zimbabwe) and intellectual property rights (IPRs) are the contemporary empirical cases considered here. The article concludes with some thoughts on alternatives to current uses of property rights, and what the consequences may be of a continually expanding property rights regime.

\section{The Origins of Dispossession in the Liberal Idea of Private Property}

John Locke's is the first comprehensive attempt - the embryonic liberal argument - at joining private property in an 'inseparable union' with freedom (Kelsen, 1955, p. 86). ${ }^{3}$ That (in nature) to which man joins his labour becomes his property, a right from which he cannot be alienated: 'He by his labour does, as it were, inclose it from the Common' (Locke, 1967, p. 308). Crucial to Locke's argument, however, is the notion that while no other person can have a right to this property, this is only the case 'where there is enough, and as good left in common for others' (p. 306). This critical concern with what is left for others is unfortunately left aside, both in terms of the overall emphasis in Locke's own writings on property, and especially in the case of transferring Locke's arguments on property into the basis for legal ownership - Rousseau's 'clever usurpation' made into 'irrevocable right' (compare with Shrader-Frechette, 1993, p. 202). The history of global accumulation provides ample proof that the right to property at all times trumps the concern for 'enough and as good left in common' for others and the rights of those who, in the process of accumulation, are left without.

Transforming the liberal idea of a right to private property into law sets the parameters within which any discourse on rich and poor, on 'haves' and 'have-nots', on what can and ought to be done about extremely unequal patterns of resource distribution can be held. Modern liberal thinkers retain Locke's emphasis on private property and the laws upholding them as essential for human freedom (Hayek, 1973) and also for socio-economic development (de Soto, 2000). Gray left no doubt regarding the importance of private property as a necessary component of freedom and integral to the very possibility of a modern, complex society.

The free market represents the only noncoercive means of coordinating activity in a complex industrial society ... Private property is the embodiment of individual liberty in its most primordial form and market freedoms are indivisible components of the basic liberties of the person (Gray, 1995, p. 61, emphasis added). ${ }^{4}$

For Rousseau, as well as modern critics of property (for example, Perelman, 2002), such sentiments simply 'legitimise' exploitation by the powerful in society. Given a sustained criticism of the origins of concepts of justice and private property in liberal thinking, it becomes essential to the liberal project to refute claims that capital accumulation is based on inherent injustices and is violent in both its nature and consequences. Hence, an intense emphasis on the 'emancipatory' 
potential of private property and capitalism, and the supposedly 'optimal outcomes' to be gained from basing the organisation of society on such foundations. Moreover, the devastating consequences of challenges to the liberal world order in the twentieth century - the 'really existing' state socialism of the Soviet Union and Nazi-led fascism - helped liberals make the case that there was indeed 'no alternative' to a (Western-led) capitalist world order.

Because liberal thinkers associate most ills of modern history with the absence of liberal values and institutions, the idea that property rights are essential to development and freedom is never challenged in mainstream development thinking; right to property is proclaimed a human right in Article 17 of the 1948 UN Universal Declaration of Human Rights. Leading institutional authorities praise property rights as the cornerstone for any hope of socio-economic development. De Soto's (2000) influential tract on 'the mystery of capital' proclaims that universalising property rights is the key to development outside the West where capitalism has previously 'failed everywhere'; never mind that dispossession always accompanied Western universalising of property rights. For Fukuyama (2004), history may have come to an end but 'capable states' that can maintain law and enforce property rights are still crucial for development and stability.

In a recent keynote speech to the African Economic Research Consortium, First Deputy Managing Director of the IMF Anne O. Krueger (2003) stresses that strong enforcement of property rights is central to any hopes for development in Africa. In the proposal for its Comprehensive Development Framework, the World Bank's President James D. Wolfensohn (1999, p. 10, emphasis added) stated bluntly that, 'Without the protection of human and property rights, and a comprehensive framework of laws, no equitable development is possible.' The World Bank's forthcoming World Development Report 2005: Improving the Investment Climate for Growth and Poverty Reduction (2004) features an entire chapter on the importance of securing property rights. Taking for granted the value of property rights prevents critical inquiry into their origins and how they are used to extend systems of oppression and exploitation globally.

Representatives of these institutions undoubtedly argue that property rights are important to safeguard for everyone, including the poor and marginalised. They do not (explicitly) advocate that only the property rights of powerful individuals, corporations and institutions should be enforced. The United Nations Development Programme (UNDP), generally articulating a (less influential) position to the 'left' of the World Bank and IMF, criticises over-reliance on the importance of property rights. Its 1999 Human Development Report 1999: Globalization with a Human Face warns of the negative impact on developing societies of taking the application of IPRs 'too far' when, for example, claiming property in manufacturing processes and biological materials. 'Poor people and poor countries risk being pushed to the margin in this proprietary regime controlling the world's knowledge' (UNDP, 1999, p. 6). 
Primitive accumulation continues to play an important role in the development of modern capitalism (Perelman, 2000, p. 12); in fact, 'capitalist imperialism even in its most mature form requires extra-economic support. Extra economic force is clearly essential to the maintenance of economic coercion itself' (Wood, 2003, p. 4, emphasis added). ${ }^{5}$ By examining and comparing more 'traditional' forms of dispossession with more 'sophisticated' ones, it is possible to discern a similarity in both use of the concept of property rights (extending it across type) and the violent, indeed lethal, consequences of dispossession by means of extending and enforcing property rights across space. In practice, the moment of actual dispossession oftentimes precedes the conceptualisation of property rights and the legal application of those rights.

\section{Expanding the Sphere of Dispossession}

A 'sphere of dispossession' has expanded across two dimensions of property rights, consequently shrinking the 'development space' (compare with Wade, 2003) available to governments and peoples in the Global South (see Figure 1).

Over time, property rights have expanded from a relatively basic notion of what constitutes property that, consequently, can be owned and restricted from use by others (the 'y axis' in Figure 1). At an early capitalist/industrial stage the concept of property rights pertains to tangible items like a piece of land, basic commodities (clothes, food etc.) and labour. With deepening (increasing) commodification over the last few centuries, the concept of what can, and ought to, be classified as property has expanded considerably. Today, the most sophisticated forms of property are those generally referred to as 'IPRs'. In their most sophisticated form they extend the concept of property rights to 'commodities' like manufacturing processes and biological materials. Since 1980, the US Patent Office awards patents on the cellular structure of living organisms. In Iceland, rights to market the population's genetic code have been purchased from the Icelandic government by a private corporation (Decode), and this corporation has in turn granted a Swiss biotechnology company (Hoffman-La Roche) exclusive rights to access this data.

There has also been an extension in the (spatial) range of application and enforcement of these property rights (the ' $x$ axis' in Figure 1). From application and enforcement at the local/domestic level, the 'reach' of property rights has become truly global. Initially, this extension occurs along with imperial expansion. In addition, the instruments by which states enforce property rights have become increasingly complex. In the early capitalist/industrial era, property rights covering basic forms of property were enforced by the Weberian monopoly on the use of violence enjoyed by the state. Today the global reach of property rights is enforced also via the structural power of dominant actors in the international arena, specifically via international institutions like the WTO and the World Intellectual Property Organization (WIPO), and policies like the Agreement on 
Figure 1: Extending the 'sphere of dispossession'

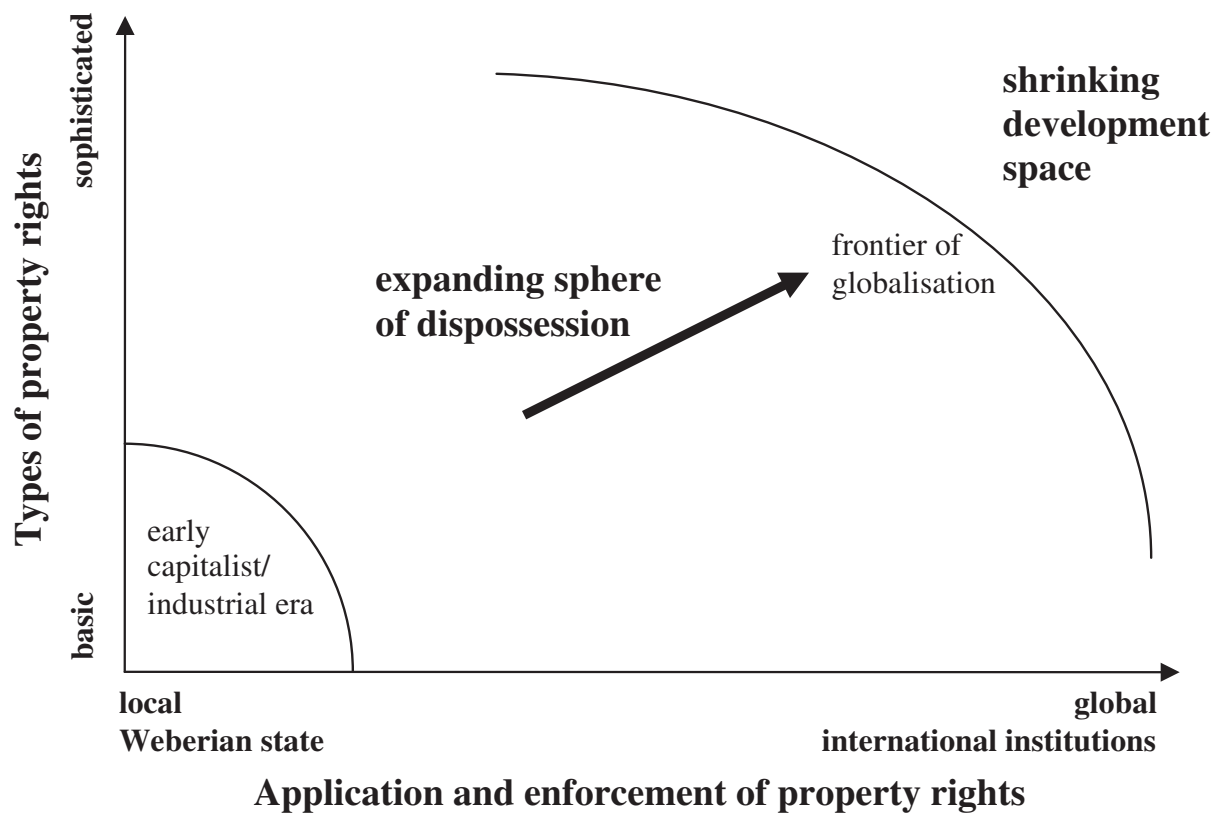

Trade-Related Aspects of Intellectual Property Rights (TRIPS). This extension of property rights - both in terms of that to which they apply and the range within which they are applied - further erodes possibilities for broad-based development globally as well as any hope of mitigating increasing global polarisation of wealth and knowledge (compare with Wade, 2003).

\section{The Many Faces of Dispossession}

The early capitalist era provides an impressive catalogue of violence associated with the expansion of markets, ownership and European imperial power. Spread of property regimes and capitalist market imperatives from the European metropoles outwards have generated widespread resistance. Enclosure movements in England, which according to Marx (1990, pp. 883-4) 'had the same effect on the English labourer, mutatis mutandis, as the edict of the Tartar Boris Godunov had on the Russian peasantry', triggered rebellions, as did the wholesale dispossession of peoples originally living on the land in colonial Southern Africa (Phimister, 1988; Ranger, 1967). Marginalisation yields desperation, and people are not in all cases content to simply go away quietly to starve, or die. When heeding the capitalist logic of migrating to urban areas in the 'hope' of joining an emerging proletariat, they end up exacerbating societal strains caused by 
dispossession while oftentimes not improving their situation. The desperation of their situation produces various forms of resistance, both 'legal' and 'illegal', and when laws are broken the state will step in to enforce them, with violent means if necessary. ${ }^{6}$

Even when the results of large-scale dispossession became more or less accepted as new 'facts on the ground', capitalists, and classical liberal thinkers, were deeply concerned with the fact that workers did not seem to prefer their new existence as labourers lacking other means for self-subsistence (Perelman, 2000, pp. 16-24). If the goal of 'cleaning' the peasants off the land in England was to drive them into factories, comparable processes of driving southern Africans off their lands increased their willingness to labour on European settlers' farms and mines in Rhodesia (Phimister, 1988, pp. 77-80) and South Africa (Beinart, 1994, pp. 25-34; Lipton, 1986, pp. 88-91). Extending the regime of private property, which lessens disproportionately the options and resources available to people at the lower end of social strata (Katz, 1997), provides the key means for producing dependency, obedience and a 'willingness' to be exploited in those rendered without even the basic means of (independent) subsistence. Struggles over land and property in Southern Africa and global expansion of IPRs provide good examples of how traditional and sophisticated uses of property rights are combined in the post-colonial era.

\section{Land Struggle in Southern Africa}

In Capital, Marx (1990, p. 889) notes that by the nineteenth century, 'the very memory of connection between the agricultural labourer and communal property had ... vanished' in England as a result of centuries of dispossession by means of enclosures and related measures. In former European colonies, where widespread land-grabbing and forced removals produced today's patterns of highly unequal land ownership and uneven development, indigenous peoples are recalling the historical processes by which they were collectively, as peoples, rendered landless and dependent. Indeed, the Zimbabwean land occupations beginning in the late 1990s 'are a manifestation of a much larger phenomenon currently under way across the South' (Moyo, 2001, p. 311). On the other hand, rhetoric emanating from the West and the international financial institutions about respect for property rights, and for those who are able to use the land 'properly' (effectively) seems to indicate precisely the sort of 'forgetting' that Marx deplored in the case of nineteenth-century England. ${ }^{7}$

Controversies surrounding recent struggles to reclaim lands appropriated during European colonial expansion are instructive for understanding contrasting views on the 'right' to property. On the one hand there is some recognition and lamenting of the fact that so many people lack the bare minimum of resources needed for survival. On the other hand there is a continued insistence on the sanctity of property rights and the need to make 'efficient use' of whatever sort of 
property may be disputed. 'Efficient use' generally means the ability to maximise the return on investment and generation of profit on any given piece of property (whether a product or a piece of land), rather than gearing the use of that property to those most in need. In the case of the land redistribution controversy in present-day Southern Africa, the argument emanating from the propertied classes emphasises the inability of landless Africans to make 'good use' of the land and their lack of the means (in most cases) to 'clear' legal claims on the land. ${ }^{8}$ The violence and corruption accompanying recent attempts to resolve the land controversy in Zimbabwe has increased the confusion regarding property rights and land ownership in the region and beyond.

Zimbabweans have inherited an extremely uneven land ownership, the result of generations of uneven development producing a highly dualistic economy (Bond, 1998). At independence in 1980, some 700,000 smallholders occupied about 49 percent of all farming land (16.4 million hectares), mostly in less favoured and productive parts of the country, and 5,000 to 6,000 white largescale commercial farmers owned 46 percent of the total farming land (15.5 million hectares) (Kinsey, 1999, p. 177). The newly independent Zimbabwean government made land reform one of its prominent post-independence projects, but it was also seriously constrained by dependence on the Lancaster House agreement with Britain (in effect from 1980-90) to fund land reform (Bernstein, 2003, p. 212).

Land reform in the early 1980s, which Kinsey (1999, p. 177) noted 'dwarfs all other efforts' in sub-Saharan Africa, resulted in some concrete benefits for peasants but tapered off by the end of the decade. A subsequent Land Acquisition act in 1992 did not manage to revive the land reform process in any meaningful way (Dashwood, 2000, p. 181). By the late 1990s, on the eve of the current wave of 'primitive' accumulation which has resulted in many political leaders acquiring much of the land expropriated from white commercial farmers, only about 70,000 landless families had been resettled on appropriated land, far short of the early independence goal of 162,000 families (Kinsey, 1999, p. 176). ${ }^{9}$

The most recent violent and chaotic land redistribution is 'unparalleled in the country's history'; about 11 million hectares of land was redistributed in 2000-02 alone, with an estimated 90 percent of white commercial farmers having their land expropriated by the government (Sachikonye, 2003, p. 24). Three hundred thousand small-hold settlers, and 30,000 black commercial farmers have received land via this process, although only five percent of farm labourers on the expropriated farms have received any land, making them the primary 'losers' (economically and socially) in this process (Rutherford, 2003; Sachikonye, 2003, p. 25).

Much of the land expropriated by government has, however, been portioned out to sustain the government's neo-patrimonial networks, rather than for the benefit of poor peasants, and no clear tenure patterns have emerged. The Mail and 
Guardian (Johannesburg, 10 July 2002) reports that many senior government officials, two vice-presidents, officers in the military, war veterans, intelligence officers, state media journalists, and relatives of President Mugabe have taken farms under the current land redistribution scheme. The situation is in flux, and while 'moderates' within the ruling party, and even President Mugabe, have called for 'one man, one farm', the problem of how to properly transfer land to landless Zimbabweans able to make use of it has not been resolved (Ncube, 2004). Where peasants have received land, government has generally failed to provide appropriate support to the new tenants, thus exacerbating problems of confiscated lands laying fallow and resettled peasants lacking training and agricultural inputs (for example, grains and tools) necessary for the land to become productive again (Sachikonye, 2002, p. 18; Zulu and Mukaro, 2002).

These developments can be interpreted as an ongoing process of primitive accumulation (redistributing control of property from white to black elites) that serves the complex political needs of the state as much as it is a process geared towards the social and economic ends of rectifying historical injustices (compare with Hammar et al., 2003). The beginning of major land occupations in February 2000 was partly a direct response by government to the defeat in a national referendum that same month of its proposed new constitution and also orchestrated as a response to a combination of emerging threats. A legacy of the 1990s structural adjustment programmes, economic crisis from 1997 onward, prompted social unrest and increasing agitation by war veterans (Moyo, 2001, pp. 314-8). The Movement for Democratic Change (MDC) and its leader, the former trade union leader Morgan Tsvangirai, emerged in 1999 as a serious challenge to the Zimbabwe African National Union-Patriotic Front government and enjoyed significant backing from white capital. The MDC opposition nearly gained a parliamentary majority (winning 57 of 120 contested seats) in the June 2000 elections (Bond and Manyanya, 2003, pp. 70-80). Thus, white farmers and (later on) businessmen, and their black MDC compatriots, became perceived by government as an acute threat to be neutralised.

This current struggle, over political and economic control as well as over land, pits (primarily) two groups of elite interests against each other. Government elites have enriched themselves via this recent round of accumulation by expropriation, but they also constitute a comprador class that has been rather acquiescent to the demands of international and domestic capital interests during the majority of its two decades in power (Bond, 1998). This government elite is clashing not only with commercial farmers whose land ownership is, largely, a legacy of colonial and apartheid-style accumulation, but also with the Zimbabwean people rendered increasingly desperate by the combined economic, political and societal crisis; the volatility of the war veterans is a threat to them all. Whether old patterns of land ownership remain intact or slightly altered (as has been the commercial farmers' goal), or whether the current government eventually manages to expropriate all land in order to purchase some additional allegiance from its 
crucial supporters among elites and armed militants, the issue of how the land can be used to benefit those most in need remains neglected.

If the poor are to benefit at all, it must (from the elite's perspective) seemingly be via the 'benevolent agency' of either the commercial farmers that have enjoyed property rights to most fertile land, or via the government that should repossess the land and then redistribute it in an appropriate manner. Farmers insist that they must possess the land so that it can produce for the 'benefit of all'. The government insists that it must acquire possession of the land in order to facilitate 'ownership for the people'. Both cases are arguably rhetorical attempts to mask the politics of dispossession. Much of the land has indeed been productive, and the farmers (who have now also been dispossessed) and their labourers have invested greatly in it. This is the central claim, along with the argument that it is important to respect property rights, put forth by the Zimbabwean commercial farmers as to why major land redistribution may be counterproductive. The farmers have been successful at convincing the 'international community' (Western governments) that they are the country's 'breadbasket' (Moore, 2001, p. 912); however, the profits made have, to a significant degree, sustained luxury consumption for wealthy Zimbabweans (compare with Cliffe, 2000). ${ }^{10}$

The theoretical debate on land reform is also polarised. Thomas (2003) makes a strong case for radical land reform in Zimbabwe on ethical and economic grounds. He rejects notions that commercial-sector farming is more efficient than peasant farming and that land redistribution will not benefit the poor. Ethically, land redistribution would 'increase equality and hence social justice ... it is imperative to right past wrongs'. This is also a prerequisite for future political stability (Thomas, 2003, pp. 694-5). Economically, under-utilised areas must fulfil their productive potential. As there is an 'inverse relationship' between land-holding size and the following: land utilisation, proportion of land cropped, proportion of crops that are food crops and productivity per hectare, radical land reform makes economic sense (p. 696). The idea that black farmers must be less efficient is no more than an old (racial) prejudice given that many large commercial farms have been managed for absentee landlords by blacks (p. 703). Finally, 'similarities between Zimbabwe and South Africa are indeed striking' when it comes to the historical fact of unequal land distribution and increasing demands that this situation be rectified. Thus the case of Zimbabwe will be instructive for 'similar processes' unfolding in Botswana, Namibia and South Africa (p. 691). ${ }^{11}$

Shaw (2003) presents a sweeping refutation of the claims made by the Zimbabwean government and many black Zimbabweans on the lands of the country's commercial farmers. While Shaw is not opposed to land reform in all circumstances, he sees no justification for the process that is currently unfolding. First, he argues that the peasants do not need the land, because giving them land is not likely to alleviate their poverty. Second, black (and some white) Zimbabweans did not necessarily fight for the land, but rather to end 'Rhodesian-style apartheid'. Third, the land was not stolen from the Africans tout 
court, and because of the many complex ways in which land was conquered and re-conquered, used and otherwise disposed of in pre-colonial Zimbabwe, there would in any case not be any clearly identifiable 'rightful owners' to which the land could be returned (Shaw, 2003, pp. 82-3). In arguing that those Europeans who came to own the vast majority of fertile lands in Zimbabwe may have been entitled to take possession of it, Shaw (p. 82) relies on the theories of Locke (1967) and Nozick (1974) where 'previously unowned' resources become owned once one has mixed one's labour with them (which, according to Shaw, the Europeans did but the Africans, presumably, did not). ${ }^{12}$

The 'reverse land grabbing' occurring in Zimbabwe today is considered dangerous not only because it is violent and results in real injustices for many individual farmers and their labourers. Beyond that immediate concern, there is also a (greater) worry among propertied classes that the idea of property rights being sacrosanct is being eroded. A historical 'accounting' of the means by which propertied classes worldwide have acquired their possessions would become unpleasant indeed for those interested in preserving the status quo of global inequality and the 'rights' which impede any radical rectification thereof - Moyo (2001) and Thomas (2003) suggest such processes of accounting are already unfolding. While these issues remain unresolved (for now), property rights are expanding into new, more sophisticated realms.

\section{Intellectual Property Rights - the New Frontier of Dispossession}

IPRs represent the cutting edge of expanding the concept of property rights, and thus the ability to control and restrict the use of items we traditionally have not thought of as constituting property - for example, biological processes and genetic code. ${ }^{13}$ IPRs amount to the 'commodification of nature in all its forms', and the discovery of such 'rights' has opened up 'wholly new mechanisms of accumulation by dispossession' (Harvey, 2003, p. 147). From an economic perspective, IPRs constitute a 'temporary monopoly on the use of knowledge' (Lall, 2003, p. 1659). Of particular importance is TRIPS, which was negotiated during the WTO's Uruguay Round (1986-94) and has been operational since 1994 the 'culmination of a general strategy on the part of the USA and EU to force developing countries to adopt multilateral agreements in sectors which they had hitherto resisted' (May, 2004, p. 822).

TRIPS covers the guaranteeing of property rights in trademarks, copyrights, industrial designs, data secrets and patents - the two most important being patents and copyrights. A plethora of institutions and agencies have emerged to help (and ensure that) developing countries comply with TRIPS regulations. These agencies are supported by, among others, organisations like the European Patent Office, the WTO, the UN Conference on Trade and Development, the WIPO, the US Department of Commerce and the Rockefeller and Ford Foundations. 
Non-governmental organisations like Oxfam, Action Aid and Médicins Sans Frontières have, rather unsuccessfully, attempted to help policymakers and legislators in developing countries resist wholesale acceptance of full-scale TRIPS and related regulation (May, 2004, pp. 825-8).

Arguments justifying IPRs rely on liberal theories of property and a positivesum conceptualisation of North-South relations. In theory, IPRs stimulate creativity and innovation, generate technological diffusion and dissemination of knowledge and promote the uses of new technology in production (Lall, 2003, pp. 1659-60); they offer a variety of potential economic benefits to countries adopting these rights, thus enabling development in the South where underdevelopment is often linked to deficiencies in the very areas that IPRs are intended to enhance. Lall (p. 1660) also notes potential costs of IPRs, such as higher prices for imported products and technologies affected by these IPRs, loss of economic activity when 'imitative activities' seen as infringing on these IPRs are forced to close down and 'the possible abuse of protection by patent holders, especially large foreign companies'. Most of these adverse effects are understood as shortterm, with the long-term benefits of applying IPRs outweighing costs.

May (2000) disputes this optimistic understanding of the consequences of IPRs and considers the extension of property rights into the 'intellectual' domain an example of the 'new enclosures' of the global economy. For May, the quest by corporations to seek private rewards from IPRs outweighs the prospects of those rights generating public goods (in terms of spurring technological investment, the fruits of which can be diffused beyond the corporations/entities involved). According to Perelman (2002, p. 4), 'costs are socialized, while benefits are privatized'.

Wade (2003) provides an indictment of TRIPS and related agreements by emphasising their deleterious effects on the possibility for developing countries to implement effective development strategies. A major problem is that the duties and rights mandated by TRIPS are seriously skewed in favour of the developed world. While obligations of developed countries tend to be vague and unenforceable, the obligations of developing countries are specific and enforceable. Furthermore, many bilateral trade agreements between developed and developing nations use TRIPS as the base line agreement, and then aim to impose additional restrictions (with regard to IPRs) that are even more skewed in favour of the (commercial) interests of the developed countries who possess the vast majority of intellectual properties.

TRIPS exacerbates the already unbalanced flow of capital from South to North as developed countries are net producers of intellectual property and developing countries are net consumers. The vast majority of intellectual property is patented in Organisation for Economic Co-Operation and Development (OECD) countries, which raises further the cost of knowledge for countries, institutions and individuals in the South. In 1993, ten countries accounted for 
84 percent of global research and development expenditures; wealthy countries now hold 97 percent of global patents and 80 percent of patents in the South are held by residents in the North (Perelman, 2002, p. 6). OECD countries accounted for 19 percent of world population and 91 percent of all new patents issued in 1998 (UNDP, 2001).

The argument that enforcing IPRs would increase generation of technology and knowledge in the North, the use of which could then 'trickle down' to consumers in the South, does not, like most economic arguments predicated on market-driven trickle down effects, seem to pan out. Whether it is patents on processes or copyright of scientific publications concentrated in the North, the knowledge gap between North and South inevitably widens when property rights are applied in a more sophisticated manner (Wade, 2003, p. 624).

As most natural science research is being privatised, less and less research is being done on issues from which the researchers and right holders are unlikely to receive a significant economic pay-off. This includes many problem areas of primary interest to populations in developing countries (Wade, 2003, p. 624).

'Biopiracy' is yet another problem of the expanding IPRs regime. Biopiracy is rooted in the Western concept of Terra Nullius, meaning that if a corporation or other organisation (usually from the North) 'discovers' useful plants, microorganisms or other items that do not 'properly belong' to anyone (but may have been used by indigenous populations for ages) it can turn these items, or their specific usages, into 'inventions' that become legal property and thus more costly or not available for others to use (Shiva, 2000, p. 503). Thus, biopiracy becomes yet another weapon in the arsenal of global dispossession of the already poor by the already rich.

The expansion of property rights, and various other measures that effectively restrict the policy options of developing countries, shrinks the 'development space' in these countries by means of 'proliferating regulations formulated and enforced by international organizations' (Wade, 2003, p. 621). Developed countries, led by the USA and the UK, use 'multilateral economic institutions, international treaties and bilateral agreements', rather than the cruder means of past imperial coercion, to entrench their favourable bargaining positions in international economic relations (p. 622). According to former World Bank Chief Economist and Nobel Laureate Joseph Stiglitz's popularised commentary on the ills of globalisation as currently managed,

the underlying problems - the fact that the intellectual property regime established under the Uruguay Round was not balanced, that it overwhelmingly reflected the interests and perspectives of the producers, as opposed to the users, whether in developed or developing countries - remain (Stiglitz, 2002, p. 8).

Neo-liberal reforms erode steadily the capacity of governments in developing countries to implement strategic development plans. They also create a 
'rapacious' bourgeoisie, able to take advantage of these reforms to enrich themselves; the state is thus helping create a new round of accumulation for this emergent capitalist class. ${ }^{14}$ Once liberalisation and privatisation sufficiently denudes the state's bargaining power vis-à-vis capital, the state is forced to rely on marketdriven strategies for development. Such strategies entail appeasing capital demands for 'market-friendly' policies and hoping that any engagement with capital interests will 'trickle down' and thus become available for development ends. The history of increasing reliance on neo-liberal development strategies suggests that the expected benefits do not materialise for most of the world's poor (Chang, 2002; Rist, 2002).

In the end, the lethal effects of, for example, patents on HIV/AIDS antiretroviral drugs and other medicines for people too poor to afford such drugs at market prices are comparable to the deadly effects of enclosure movements of the past for those peasants deprived of their livelihood and unable to replace it with something else. In both cases, when these forms of dispossession generate resistance, the law of the State will generally weigh in on the side of the propertied (whether multinational pharmaceutical companies today or landed gentry then) with dire consequences for those challenging the legal status of property. ${ }^{15}$ In the case of HIV/AIDS anti-retroviral drugs, however, global campaigns have been able to challenge some aspects of IPRs. The Treatment Action Campaign in South Africa has worked successfully with civil society to compel multinational pharmaceutical companies into withdrawing legal action against the South African government for providing access to affordable generic drugs in 2001 and then pressured the South African government to actually provide anti-retroviral drugs to HIV/AIDS sufferers in 2003 (Mbali, 2004).

Major pharmaceutical multinationals have given in to some demands for affordable generic drugs and WTO rules on IPRs have consequently been modified to allow developing countries to manufacture some generic drugs. But even in such cases of apparent victory against a property rights regime, the complexity of the 2003 WTO agreement has, according to World Health Organization spokesperson Daniela Bagozzi, apparently resulted in 'no country [having] issued a demand for a compulsory license [to manufacture generic drugs] as authorised in the agreement'. Furthermore, the USA has, according to one UNAIDS official, decided to protect its pharmaceutical industry 'by putting pressure on small countries ... not to take advantage of the [WTO] agreement' (Business Report, Johannesburg, 8 March 2004). The neo-liberal shift in world politics during recent decades further stacks the deck against those wishing to challenge this status quo.

\section{Property Rights as Gatekeeper and Guarantor of the Status Quo}

A key goal of the 1980s and 1990s' "neo-liberal revolution' has been the increased separation in society of the political sphere from the economic sphere. 
Disregarding the crucial role of the state in creating markets, Bates (1999) argues that such a separation is necessary for democracy to take root in Africa. Neoliberal reforms aim at securing property rights of and for the propertied classes, despite whatever other social and political reforms may be undertaken. Bernstein (2003) suggests that the 1990s' neo-liberal reforms in Zimbabwe seriously diminished the government's capability of achieving significant land reform in favour of the landless poor, as is the case with neo-liberal restructuring in post-apartheid South Africa (Hall, 2004, p. 219).

The fear of democracy as a threat to property is established early in the capitalist era. In 1792, even a 'moderate reformer' like the Reverend Christopher Wyvill saw increasing demands for democracy and inclusion by England's lower classes (Burke's 'swinish multitude') as likely to produce a chaotic situation where 'all we now possess, whether in private property or public liberty, will be at the mercy of a lawless and furious rabble' (Wyvill, quoted in Thompson, 1968, pp. 26-7). From early industrial England to post-apartheid Southern Africa, propertied classes have linked the extension of democratic rights to the poor with chaos and threats to property - a risk presumably due to the inability of the poor to respect laws, rather than any obvious injustices that may have accompanied previous amassing of property and wealth.

With the waning of state socialism and the onset of neo-liberal reforms globally, propertied classes have managed to contain the political/popular threat to private property. Following transitions to (some forms of) democracy in Eastern Europe and Russia in the early 1990s, governments moved quickly to embrace liberal notions of property, thus precipitating a new round of accumulation and radical redistribution of property, from state ownership to private ownership by small and politically well-connected elites while at the same time poverty increased for the general populations in the region. Decades of economic transformation in China produced reconciliation with liberal notions of property rights in the country's quest for WTO membership, but also increasing socioeconomic inequalities. These developments are all, according to Holmstrom and Smith (2000), a new form of 'gangster capitalism'. Hence the widespread disappointment among various 'anti-capitalist' movements when, for example, the demise of apartheid rule in Zimbabwe, Namibia and South Africa failed to produce structural transformation of these economies (Bond, 2001). This has also been the case elsewhere where existing property rights regimes have survived nominal transitions to (procedural) democracy and remain reliant upon and supported by both new political elites and entrenched economic elites.

\section{What to Do about Property?}

The application and expansion of private property is inevitably linked to dispossession. This argument stands in stark contrast to liberal theories of private property, which hold that property is primarily bestowed with emancipating and 
empowering qualities. The understanding of property put forth herein weakens considerably this liberal claim. If property can emancipate and empower, it tends to do so very selectively and unevenly. The net effect of expanding forms of property and expanding enforcement of property rights, as opposed to what property rights can theoretically (and in some cases actually do) produce, is that people become dispossessed and without access to various things enabling their subsistence. De Soto's proposed 'solution', to universalise property rights, is fundamentally flawed.

If the production and expansion of private property is at the root of contemporary problems of underdevelopment and marginalisation, then what are the alternatives to current property rights regimes and predominant (liberal) conceptualisations of property? Are non-capitalist forms of socio-economic organisation viable? Is reform of the global capitalist order sufficient to overcome the processes of dispossession and marginalisation that have been outlined in this article? If a blueprint for a viable path to a 'propertyless' world order cannot be provided, then what use is it to point out that capitalist accumulation produces (many) losers as well as winners?

It is important to point out problems inherent in private property regimes, whether or not alternatives are readily available. At minimum, a clear recognition of the damaging consequences of property rights ought to suggest that all efforts possible should be invested in attempting to minimise those consequences. It is of course possible to conceive of several forms of socio-economic organisation not based on capitalist private property. History furnishes several examples: for example, pre-modern forms of communal ownership, feudalism, anti-modern ('utopian') communism, the planned economies of state socialism and so on. Contemporary property theorists examine possibilities for property rights reforms and alternatives to liberal property rights from a variety of perspectives, demonstrating that scholars, as well as people in general, do believe that alternatives to (liberal) property rights regimes can be imagined (for example, Ellsworth, 2004; Geisler and Daneker, 2000; Jacobs, 2004). Innovative ways of expanding collective forms of ownership would reduce costs of utilising what is otherwise claimed as property. More imaginative means of distributing resources based on need rather than ability to pay would make possible more efficient resource utilisation, thus diminishing the need to, in all cases, base improving living standards on increased production and consumption.

Since feudalism, however, only the planned economies of state socialism and fascist corporatism have been significant (and temporarily implemented) alternatives to liberal capitalism. Traditional, anarchist, non-authoritarian socialist, religious-ascetic and environmental-communal forms of societal organisation have so far not posed a coherent challenge to modern capitalism (and in many cases, these alternative forms of organising society are not interested in posing a challenge to capitalist society, as much as they are interested in withdrawing from it). ${ }^{16}$ The thoroughly entrenched 'historical bloc' that constitutes the intellectual, 
ideological and political hegemony underpinning the pillars of modern society - capitalism, private property and, to a much less important degree, liberal democracy (concerned primarily with procedural rights and negative freedoms) - is, as Gramsci (1994) theorised, very difficult to challenge.

This historical bloc makes any challenge to the private property-based organisation of modern society seem 'outlandish'. At root, however, there must be a solution to the dilemma of how to nourish some form of stable and 'rational' use of resources, while not at the same time relying on the denial of usage of resources by those in need of them (which is an inevitable consequence of private property rights). However this dilemma may be resolved, a further reduction of various forms of 'collective ownership' cannot be the answer. Intensifying processes of commodification and privatisation can only exacerbate problems of dispossession and marginalisation.

(Accepted: 3 September 2004)

\section{About the Author}

Stefan Andreasson, School of Politics, International Studies and Philosophy, Queen's University Belfast, 21 University Square, Belfast BT7 1NN; email: s.andreasson@qub.ac.uk

\section{Notes}

A previous version of this article was presented at the annual conference of the Political Studies Association, University of Lincoln, UK, in April 2004. The author wishes to acknowledge helpful comments from David Moore, Thom Brooks, Terrence Casey and two anonymous reviewers.

1 For two very different understandings of private property, see Locke (1967) and Proudhon (1994).

2 Capitalist accumulation is distinct from the pre-capitalist form of accumulation that Marx called 'primitive' and Adam Smith called 'previous'. Primitive accumulation refers to the process of separating the producer from the means of production, which in turn enables a capitalist accumulation where labour is already alienated and wage labour is employed by those in control of capital (Marx, 1990, pp. 873-6). Both primitive and capitalist forms of accumulation are of interest here, as they both contain elements of cruelty and violence and are both inextricably linked.

3 On Locke as the principal proponent of private property rights as integral to liberal capitalism, see also Macpherson (1962) and Strauss (1953).

4 For his much less optimistic assessment of the sustainability of global capitalism, see Gray (1998).

5 See Harvey (2003, pp. 39-40) on how the US consistently engages in military coercion to protect its hegemony and the rights of global propertied classes in the post-WWII era.

6 Death penalties for 'economic crimes' proliferated in late eighteenth-century England. In addition to petty theft, crimes associated with opposition to the new economic order, such as pulling down fences enclosing the commons, became punishable by death. In 1785, only one person of 97 executed in London and Middlesex had committed murder. The remainder of the executed were guilty of 'economic crimes', primarily offences against property (Thompson, 1968, p. 65).

7 See Moore (2004, pp. 98-9) on how the violence of primitive accumulation is conveniently forgotten in 'populist' works, like de Soto's (2000), on how to resolve global poverty today by means of universalising property rights.

8 The South African government has recently shifted its focus in land reform policy from the rural poor to 'emerging' black commercial farmers (Hall, 2004).

9 For a timeline of land redistribution in Zimbabwe since independence, see Thomas (2003, p. 707).

10 Lipton (1986, p. 106) notes that efficient, small-scale and labour-intensive farming can have a competitive edge over large-scale, capital-intensive farming based on low-paid and coerced labour in developing countries - especially in countries like Zimbabwe where large-scale agriculture mainly raises cash crops for export (compare with Moyo, 2000). 
11 See Bernstein (2003) for a comparison of the agricultural situation in Zimbabwe and South Africa.

12 For ethical arguments against land reform in South Africa, see Attfield et al. (2004, pp. 413-7).

13 See Drahos (1998) for a history of intellectual property rights.

14 Point made by David Moore in private correspondence, 2004.

15 Pharmaceutical companies were a driving force in promoting TRIPS (Wade, 2003, p. 639).

16 See Saad-Filho (2003) on challenges and alternatives to capitalism.

\section{References}

Attfield, R., Hattingh, J. and Matshabaphala, M. (2004) 'Sustainable Development, Sustainable Livelihoods and Land Reform in South Africa: A Conceptual and Ethical Inquiry', Third World Quarterly, 25 (2), 405-21.

Bates, R. H. (1999) 'The Economic Bases of Democratization', in R. Joseph (ed.), State, Conflict, and Democracy in Africa. Boulder CO: Lynne Rienner, pp. 83-94.

Beinart, W. (1994) Twentieth-Century South Africa. Oxford: Oxford University Press.

Bernstein, H. (2003) 'Land Reform in Southern Africa in World-Historical Perspective', Review of African Political Economy, 30 (96), 203-26.

Bond, P. (1998) Uneven Zimbabwe: A Study of Finance, Development, and Underdevelopment. Trenton NJ: African World Press.

Bond, P. (2001) Against Global Apartheid: South Africa Meets the World Bank, IMF and International Finance. Cape Town: University of Cape Town Press.

Bond, P. and Manyanya, M. (2003) Zimbabwe's Plunge: Exhausted Nationalism, Neoliberalism and the Search for Social Justice. London: Merlin Press.

Bracking, S. and Harrison, G. (2003) 'Africa, Imperialism and New Forms of Accumulation', Review of African Political Economy, 30 (95), 5-10.

Chang, H.-J. (2002) Kicking Away the Ladder: Development Strategy in Historical Perspective. London: Anthem.

Cliffe, L. (2000) 'The Politics of Land Reform in Zimbabwe', in C. Stoneman and T. A. S. Bowyer-Bower (eds), Land Reform in Zimbabwe: Constraints and Prospects. Aldershot: Ashgate, pp. 35-45.

Dashwood, H. S. (2000) Zimbabwe: The Political Economy of Transformation. Toronto: University of Toronto Press.

Davis, M. (2001) Late Victorian Holocausts: El Niño, Famines, and the Making of the Third World. London:Verso.

Drahos, P. (1998) 'The Universality of Intellectual Property Rights: Origins and Development', WIPO Panel Discussion on Intellectual Property and Human Rights, Geneva, 9 November. Available at http://www.wipo.int/tk/en/activities/1998/humanrights/papers/pdf/drahos.pdf

Ellsworth, L. (2004) A Place in the World: A Review of the Global Debate on Tenure Security. New York: Ford Foundation. Available at http://www.fordfound.org/publications/recent_articles/place_inthe_world.cfm

Fukuyama, F. (2004) State-Building: Governance and World Order in the 21st Century. Ithaca NY: Cornell University Press.

Geisler, C. and Daneker, G. (eds) (2000) Property and Values: Alternatives to Public and Private Ownership. Washington DC: Island Press.

Gramsci, A. (1994) Letters from Prison. Ray Rosenthal trans. New York: Columbia University Press.

Gray, J. (1995) Liberalism. Second edition. Minneapolis: Minnesota University Press.

Gray, J. (1998) False Dawn: The Delusions of Global Capitalism. London: Granta Books.

Hall, R. (2004) 'A Political Economy of Land Reform in South Africa', Review of African Political Economy, 31 (100), 213-27.

Hammar, A., Raftopolous, B. and Jensen, S. (eds) (2003) Zimbabwe's Unfinished Business: Rethinking Land, State and Nation in the Context of Crisis. Harare: Weaver Press.

Harvey, D. (2003) The New Imperialism. Oxford: Oxford University Press.

Hayek, F. A. (1973) Law, Legislation and Liberty: A New Statement on the Liberal Principles of Justice and Political Economy. London: Routledge.

Holmstrom, N. and Smith, R. (2000) 'The Necessity of Gangster Capitalism: Primitive Accumulation in Russia and China', Monthly Review, 51 (9), 1-15. 
Jacobs, H. M. (ed.) (2004) Private Property in the 21st Century: The Future of an American Ideal. Northampton: Edward Elgar.

Katz, C. J. (1997) 'Private Property Versus Markets: Democratic and Communitarian Critiques of Capitalism', American Political Science Review, 91 (2), 277-89.

Kelsen, H. (1955) 'Foundations of Democracy', Ethics, 66 (1) (Part 2), 1-101.

Kinsey, B. H. (1999) 'Growth and Equity: Emerging Evidence from Zimbabwe's Resettlement Programme', Journal of Southern African Studies, 25 (2), 173-96.

Krueger, A. O. (2003) 'The Challenge of Poverty: How the IMF Can Help Africa', Keynote Address to the African Economic Research Consortium, Nairobi, Kenya, 4 December. Available at http://www.imf.org/external/np/speeches/2003/120403.htm

Lall, S. (2003) 'Indicators of the Relative Importance of IPRS in Developing Countries', Research Policy, 32, 1657-80.

Lipton, M. (1986) Capitalism and Apartheid: South Africa, 1910-86. Hants: Wildwood House.

Locke, J. (1967 [1698]) Two Treatises of Government. Cambridge: Cambridge University Press.

Macpherson, C. B. (1962) The Political Philosophy of Possessive Individualism: Hobbes to Locke. Oxford: Clarendon Press.

Marx, K. (1990 [1867]) Capital. Volume 1. Ben Fowkes trans. London: Penguin Books.

May, C. (2000) A Global Political Economy of Property Rights: The New Enclosures? London: Routledge.

May, C. (2004) 'Capacity Building and the (Re)Production of Intellectual Property Rights', Third World Quarterly, 25 (5), 821-37.

Mbali, M. (2004) “ “Iphi-I Treatment?” Reflections on the Treatment Action Campaign (TAC) People's Health Summit'. Durban: Centre for Civil Society. Available at http://www.ukzn.ac.za/ccs/default.asp?2,40,5,435

Moore, D. (2001) 'Neoliberal Globalisation and the Triple Crisis of "Modernisation" in Africa: Zimbabwe, the Democratic Republic of the Congo and South Africa', Third World Quarterly, 22 (6), 909-29.

Moore, D. (2004) 'The Second Age of the Third World: From Primitive Accumulation to Global Public Goods?', Third World Quarterly, 25 (1), 87-109.

Moyo, S. (2000) 'The Political Economy of Land Acquisition and Redistribution in Zimbabwe: 1990-9', Journal of Southern African Studies, 26 (1), 5-28.

Moyo, S. (2001) 'The Land Occupation Movement and Democratisation in Zimbabwe: Contradictions of Neoliberalism', Millennium, 30 (20), 311-30.

Ncube, N. (2004) 'Reform Reduced to Senseless Land Grab Orgy', The Financial Gazette, 15 July, pp. 15-21. Available at http://www.fingaz.co.zw/fingaz/2004/July/July15/5977.shtml

Nozick, R. (1974) Anarchy, State, and Utopia. New York: Basic Books.

Perelman, M. (2000) The Invention of Capitalism: Classical Political Economy and the Secret History of Primitive Accumulation. Durham: Duke University Press.

Perelman, M. (2002) Steal This Idea: Intellectual Property Rights and the Corporate Confiscation of Creativity. New York: Palgrave.

Phimister, I. (1988) An Economic and Social History of Zimbabwe, 1890-48: Class Struggle and Capital Accumulation. London: Longman.

Proudhon, P.-J. (1994 [1840]) What is Property: An Inquiry into the Principle of Right and Government. Cambridge: Cambridge University Press.

Ranger, T. (1967) Revolt in Southern Rhodesia. London: Heinemann.

Rist, G. (2002) The History of Development: From Western Origins to Global Faith. London: Zed Books.

Rousseau, J.-J. (1994 [1755]) Discourse on the Origins of Inequality. Franklin Philip trans. Oxford: Oxford University Press.

Rutherford, B. (2003) 'Belonging to the Farm(er): Farm Workers, Farmers, and the Shifting Politics of Citizenship', in A. Hammar, B. Raftopolous and S. Jensen (eds), Zimbabwe's Unfinished Business: Rethinking Land, State and Nation in the Context of Crisis. Harare: Weaver Press, pp. 191-216.

Saad-Filho, A. (ed.) (2003) Anti-Capitalism: A Marxist Introduction. London: Pluto Press.

Sachikonye, L. M. (2002) 'Whither Zimbabwe? Crisis and Democratisation', Review of African Political Economy, 29 (91), 13-20. 
Sachikonye, L. M. (2003) 'The Situation of Commercial Farm Workers after Land Reform in Zimbabwe'. A report prepared for the Farm Community Trust of Zimbabwe. London: Catholic Institute of International Relations. Available at http://www.ciir.org/content/news/news/zim\%20lobbying\%20document.pdf.

Shaw, W. H. (2003) 'They Stole Our Land': Debating the Expropriation of White Farms in Zimbabwe', Journal of Modern African Studies, 41 (1), 75-89.

Shiva, V. (2000) 'North-South Conflicts in Intellectual Property Rights', Peace Review, 12 (4), 501-8.

Shrader-Frechette, K. (1993) 'Locke and Limits on Land Ownership', Journal of the History of Ideas, 54 (2), 201-19.

de Soto, H. (2000) The Mystery of Capital: Why Capitalism Triumphs in the West and Fails Everywhere Else. New York: Basic Books.

Stiglitz, J. E. (2002) Globalization and Its Discontents. London: Penguin Books.

Strauss, L. (1953) Natural Right and History. Chicago: Chicago University Press.

Thomas, N. H. (2003) 'Land Reform in Zimbabwe', Third World Quarterly, 24 (4), 691-712.

Thompson, E. P. (1968) The Making of the English Working Class. Harmondsworth: Penguin Books.

United Nations Development Programme (UNDP) (1999) Human Development Report 1999: Globalization with a Human Face. New York: Oxford University Press.

United Nations Development Programme (UNDP) (2001) Human Development Report 2001: Making New Technologies Work for Human Development. New York: Oxford University Press.

Wade, R. H. (2003) 'What Strategies are Viable for Developing Countries Today? The World Trade Organization and the Shrinking of "Development Space" ', Review of International Political Economy, 10 (4), 621-44.

Wolfensohn, J. D. (1999) 'A Proposal for a Comprehensive Development Framework', A Discussion Draft for the Board, Management and Staff of the World Bank Group, 21 January. Available at http://siteresources.worldbank.org/CDF/Resources/cdf.pdf

Wood, E. M. (2003) Empire of Capital. London:Verso.

World Bank (forthcoming 2004) World Development Report 2005: Improving the Investment Climate for Growth and Poverty Reduction. New York: Oxford University Press. Available at http://econ.worldbank.org/wdr/wdr2005/text-35620/

Zulu, B. and Mukaro, A. (2002) 'Swathes of Farms Lie Fallow as New Absentee Landlords Fail to Take Up Land', The Zimbabwe Independent, 9 August. Available at http://www.theindependent.co.zw/news/2002/August/Friday9/analysis.html 